\title{
EFFECT OF BIOTHERAPICS MADE FROM MOUSE SERUM OR RABBIT SERUM IN Trypanosoma cruzi INFECTION.
}

\author{
Fabiana Nabarro Ferraz, Franciele Karina da Veiga, Denise Lessa Aleixo, Silvana Marques de \\ Araújo.
}

Department of Basic Health Sciences, Sector of Parasitology, Universidade Estadual de Maringá, Brazil.

Corresponding author: fabiana_nabarro@hotmail.com

The use of biotherapics as an intervention in experimental models of infection is a possible means to understand the effects of these medications [1-3]. This study evaluated the immunological and parasitological effects of biotherapics that were prepared from mouse or rabbit serum uninfected (MUI or RUI groups) or chronically infected with T. cruzi (MI or RT groups), dynamization $13 \mathrm{cH}$. Male Swiss mice, 28 days of age were infected with T. cruzi-Y-strain and treated with the different biotherapics diluted in water $(1 \mathrm{~mL} / 100 \mathrm{~mL})$. The study was approved by the Ethics Committee for Experiments in Animals-UEM (protocol no. 080/2012). Using biotherapics made with mouse serum, MUI group exhibited good outcome with a pronpunced Th1 response that was attributable to a reduction of 4 -4 concentrations and decrease in IL-17 concentrations compared with the control group. However, this cytokine balance was not sufficient to promote decreased parasitemia in treated animals, likely because of a decrease in IFN- $\gamma$, thus hindering a more effective beneficial Th1 response. Ip fontrast the MI group presented a pronounced Th2 response that was attributable to incr ase if 4 and d a 4 ease in IFN- $\gamma$ concentration compared to control group. MI group exhibited the worstouteome where the cytokine balance suppressed the immune response to T. cruzi in murine infection, resulting in a significant increased parasitemia and decreased survival time. Using biotherapics made with rabbit serum, RUI group exhibited the best outcome, including decreased parasitemia, with pronounced Th1 response that was attributable to decrease in IL-4 concentrations, with no changes in TNF- $\alpha$ and IFN- $\gamma$, associated to decrease in IL-17 compared to control group. In contrast, RI group did not exhibit alterations in parasitemia but a pronounced Th2 response that was attributable to increase in IL-4 concentration, with no changes in TNF- $\alpha$ and IFN- $\gamma$, associated to decrease in IL-17 compared to control group. Results show that biotherapics that were prepared from mouse or rabbit serum uninfected or chronically infected with $T$. cruzi differentially modulate the immune system in mice infected with this protozoan. Also, results provide evidence that biotherapics prepared with serum from healthy animal performed better than one made with serum from infected animal. In the same way biotherapics prepared with serum from resistant specie performed better than one made with serum from susceptible specie.

Statement of conflict of interest: the authors declare there is no conflict of interest. 
Statement of financial support: PROAP/CAPES; Fundação Araucária. The authors had full access to all the data in this study and they take complete responsibility for the integrity of the data and the accuracy of the data analysis.

\section{References}

1. Ferraz FN, Simoni GK, Nascimento A, Melo CS, Aleixo DL, Gomes ML, et al. Different forms of administration of biotherapy $7 \mathrm{dH}$ in mice experimentally infected by Trypanosoma cruzi produce different effects. Homeopathy. 2011; 100(4): 237-243.

2. Aleixo DL, Ferraz FN, Ferreira EC, Lana M, Gomes ML, Abreu-Filho BA, et al. Highly diluted medication reduces parasitemia and improves experimental infection evolution by Trypanosoma cruzi. BMC Res Notes. 2012; 5: 352-367.

3. Ferraz FN, Veiga FK, Aleixo DL, Spack Jr M, Araújo SM. Different treatment schemes and dynamizations of Trypanosoma cruzi biotherapies: what information do they transfer to the organism in infected mice?. Homeopathy, 2016; in press.

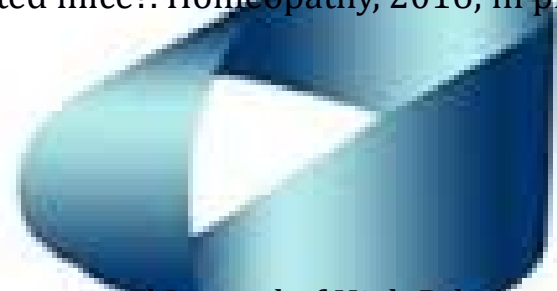

(C) Internationał

Not for commercial purposes.

$$
\text { IJHDR }
$$

